\title{
The Claims and the Use of Land by Local Communities and By the FMU of 50 Kota District in Jorong Landai, Nagari Harau, 50 Kota District, West Sumatra, Indonesia
}

\author{
Uswatul Hasana ${ }^{1}$, Mahdi ${ }^{2}$, Wilson Novarino ${ }^{3}$, Farid Azel ${ }^{4}$ \\ ${ }_{1,2,3}$ University of Andalas, Padang, West Sumatra, Indonesia \\ ${ }^{4}$ Agricultural Polytechnic, Payakumbuh, West Sumatra, Indonesia \\ Email: uswatulhasana14@gmail.com
}

\begin{abstract}
Forest Management Unit (FMU) of 50 Kota district, whose appointment by the Decree of the Minister of Forestry No. 44 / Menhut-II / 2012 on February 2, located in the 50 Kota district of West Sumatra Province, Indonesia with wide \pm 117552 ha. FMU of 50 Kota district try to make some forest management plans in certain areas such as the development for forest conservation function, production function and protected function. Local communities in 50 Kota district, some of them still dependent on the forest, and Location FMU of 50 Kota district is in the West Sumatera, that famous with the Minangkabau people with their long-existing village management system, known as Nagari. The Nagari established, to settle disputes based on customary principles as well as to protect the rights of the community members. These rights include communal land (ulayat land). In this study, has identification and attempts to describe the claims and the use of land in Jorong Landai, Nagari Harau, 50 Kota District, West Sumatra, by local communities and FMU of 50 Kota District. This research uses the descriptive qualitative method. In the Jorong Landai with a total area of $1388 \mathrm{Ha}$ with each has ulayat area as follows: Bodi: $344 \mathrm{Ha}$, Pitopang $477 \mathrm{Ha}$, Sambilan $135 \mathrm{Ha}$ and Melayu $427 \mathrm{Ha}$. The clan has used the ulayat land of 198,02 Ha for settlement, rice field, and gambir fields. The new boundaries for the area protected forest in Jorong Landai make overlapping claims of $57,01 \mathrm{Ha}$. Overlapping claims land use makes the activities local communities like blocked in their own land by the government. The primary forest in Jorong Landai of $1051 \mathrm{Ha}(267$ $\mathrm{Ha}$ in APL/Ulayat land and $784 \mathrm{Ha}$ in protection forest). Secondary forest of $63,6 \mathrm{Ha}$ (in APL/Ulayat land of $56,5 \mathrm{Ha}$ and $7,1 \mathrm{Ha}$ in protection forest).
\end{abstract}

Keywords: Claim Land Use, FMU of 50 Kota District, Local Communities.

\section{A. INTRODUCTION}

For more than 350 years Indonesia was under a colonial power. Land laws became a dualism, between colonial and traditional land laws. The land registration was complete with cadastral maps and surveys according to colonial laws, on the other hand, the various Indonesian kingdoms were stipulating their own regulations for the lands in their territories. The land traditional administration systems were different and various in each region in Indonesia. The Basic Agrarian Law (BAL) 1960, was ended in this situation by establishing a National Land Law based on the utilization of traditional concepts, principles, systems, and institutions. The land status can divide into state land or private land (Heryani, 2004). 
In rural areas, the land is the basis for agricultural production and the source for securing natural resources through fishing, hunting, pasturing or other activities. The land is used by many people for different purposes (e.g. for agricultural production, housing, industry, services, and government). The land also has social, cultural and political functions related to each country's history. Because land is used for so many purposes, land and property rights have a broad impact on people's lives and livelihoods. These rights refer to the rules that specify who can do what with which resources and assets, for how long and under what conditions. Collecting plants in a forest, cultivating a plot of land, getting the produce harvested, accessing and extracting natural resources and deciding who should or should not be allowed to collect plants or cultivate a plot of land are all expressions of the exercise of property rights (FAO, 2010).

Various land use practice is based on customary practices of communal ownership have persisted even in areas where land is registered. This is especially so in areas where the land of use practices are driven by the diversity of soil types and related crop diversity. Under such conditions, communities have continued to use customary rules of access to multiple sites e.g. salt lakes, water points instead of relying solely on their registered parcels (Waiganjo and Ngugi, 2001). Historically, most rural lands were owned and governed by local communities and indigenous peoples under customary tenure systems.

Over time, however, large areas of these lands have been also claimed by states under statutory law. In much of the so-called "developed world," this assertion of state claims has led to the reallocation of community lands to households and corporations as private property, though public ownership has remained important in some countries. In developing countries, states have often continued to assert direct claims over community lands, resulting in a situation of overlapping claims to lands that extend across large areas of the world to this day (RRI, 2015).

\section{B. MATERIAL AND METHODS}

The FMU of 50 Kota district a strategic position in the area of West Sumatra Province and the adjacent province of Riau. Jorong Landai was the area that is a part of FMU of 50 Kota district. Based on the results identification natural potential, there are potential environmental services in the Jorong Landai Nagari Harau, Harau sub-district, 50 Kota District, West Sumatera (RPHJP KPHL 50 Kota). The area in Jorong Landai, are recognized as ulayat land by local communities and the state claim some area in Jorong Landai as protected forest, causing imbalances and miss understanding in management forest between local communities and the state in Jorong Landai.

The research method is qualitative descriptive. Techniques collected data are interview, documentation, and then observation (supported by primary and secondary data sources). The identification of field conditions of land use with observation data in the field and created through QJis. 
Some of the reasons for choosing this method: 1) to adjust the method is easy. When faced with the plural reality complexity problem. 2) This method of serving directly the nature of the relationship between researcher and informants, 3), This method is more sensitive and more able to adjust a lot of sharpening joint effect of these patterns of face value (Moleong, 2004). This method can also describe the abstraction of a wide range of alternative development partnerships with the private sector of local government theoretically critically and objectively. Another reason is that the method of choosing one's own understanding of more qualitative issues that are based on perceptions, thoughts exploration, explanation, and development of concepts.

\section{RESULTS AND DISCUSSION}

\section{Local Communities In the Jorong Landai}

Jorong Landai has 399 households, has the main job as a farmer. The land to the plantation by farmers in Jorong Landai, island given to children in the lineage (the next generation of a traditional family) called ulayat land. The ulayat land in Jorong Landai is organizing by the leader of the clan, that known as Datuak. In Jorong Landai there are 4 clans namely Melayu, Pitopang, Bodi and Sambilan.

Table 1. Information on the Clan and Name of Datuak in the Jorong Landai

\begin{tabular}{|c|c|c|c|}
\hline No & The Clan & Name of Datuak & $\begin{array}{l}\text { Evidence of Ulayat land } \\
\text { ownership }\end{array}$ \\
\hline 1 & Melayu & $\begin{array}{ll}\text { - } & \text { Datuak Mangkuto } \\
\text { - } & \text { Datuak } \\
& \text { Mangkudun }\end{array}$ & $\begin{array}{l}\text { Landscape sign } \\
\text { (Malancah waterfall until } \\
\text { Kumayan Hill }\end{array}$ \\
\hline 2 & Bodi & $\begin{array}{ll}\text { - } & \text { Datuak Duko Basa } \\
\text { - } & \text { Datuak Sabatang }\end{array}$ & $\begin{array}{l}\text { Landscape sign } \\
\text { (Malancah waterfall until } \\
\text { part of Landai village) }\end{array}$ \\
\hline 3 & Sambilan & - Datuak Ndaro & $\begin{array}{l}\text { Landscape sign (part of } \\
\text { Kumayan hill until Datar } \\
\text { river) }\end{array}$ \\
\hline 4 & Pitopang & $\begin{array}{ll}\text { - } & \text { Datuak Pucuak } \\
\text { - } & \text { Datuak Mangun }\end{array}$ & $\begin{array}{l}\text { Landscape sign } \\
\text { (Malancah waterfall until } \\
\text { Sanggul Hill) }\end{array}$ \\
\hline
\end{tabular}

The Datuak has responsibilities for organizing and manage ulayat land in his clan. Datuak is a designation of customary Pusako in a clan or a people given to a person in a clan through customary ceremonies, under certain conditions according to the tradition of Minangkabau. Datuak is a leader (Penghulu) of the clan or his people and at the same time becomes Ninik Mamak in his Nagari, with a more detailed understanding again: Datuak is a designation, Penghulu is an occupation and Ninik Mamak is an 
institution in his Nagari. As Datuak he must maintain his dignity because the designation of Datuak he bears is the title of the greatness of indigenous heirlooms in a clan or his people, many taboos and restrictions that should not be violated by someone who holds Datuak and not a few positive qualities that must have it.

The Panghulu, he must know his duties and responsibilities towards his brothers/sisters and nephews in fostering, protecting and managing the utilization of high Pusako treasures (ulayat land), besides that, he must also carry out his duties and responsibilities as the head of his household to the children and his wife "Anak dipangku jo pancarian, kamanakan di bimbiang jo pusako" and as a member of the Ninik Mamak he is the representative of his clan like a member of the government (in Minang term called Andiko) in the Nagari government representing his constituents to convey for the aspirations of the people he leads and to help solve the problems that arise in his nephew children in Nagari "Andiko di dalam kampung kusuik nan kamanyalasaian, karuah nan mampajaniah".

\section{Ulayat Land History and Advent of FMU of 50 Kota District in Jorong Landai}

Jorong Landai included to Nagari Harau, is empty land formerly. Due to the urgent struggle in the Dutch era, the Minangkabau people who are in Nagari Harau, began gradually to find another place. Then the expedition various direction and found the new areas that we know the Jorong Landai today. The Minangkabau people who have the custom system (adat basandi syarak, syarak basandi kitabullah) begin to implement deliberation in determining local government (Ninik Mamak). In addition to the determination of Ninik Mamak also determine the name of the area they have occupied. Ninik Mamak has been determined according to the proposed clan of each people and set Datuak Pucuak as the head Penghulu (Leader). While the determination of the boundaries of ulayat land according to each clan is determined through the landscape (hill / mountain, river, rice field, tree, etc.) for each clan in Jorong Landai.

Traditionally the Minang people live in clusters in an autonomous genealogical and territorial ties, with collective rule based on adat law in a system of government called Nagari. Furthermore after the independence of Indonesia, the existence of Nagari in West Sumatra it is recognized as the lowest form of government (village or village level). Nagari as a genealogical-territorial entity formed because of the alliance of groups formed based on matrilineal lineage with a certain area called ulayat. The leaders in the Nagari are called Penghulu, who are the ones with the power that is sustained by the existence of ulayat land and extended family. These leaders are termed by Kemal (2009) as a genealogical group (Astuti, 2010).

According to Medalin 2018, said that if examined through the land law, the actual land law recognizes the existence of customary land, which is in article 3 of the land law. This is also related to the existence of customary land rights in West Sumatra and enforced by local communities there. the overall total area of ulayat land registered or 
unregistered in national defense affairs reached 358.90 ha located in 3,388 locations (19 regions spread across western Sumatra with 50 cities and payakumbuh cities that apply more about ulayat land authority.

The ulayat land has been recognize for a long time ago until now and handed down for generations by local communities in the Jorong Landai, used for cultivation, for shelter, to survive, etc. In 2012, the government claims part of areas in Jorong Landai as protected forest, under the authority of the FMU of 50 Kota district. The Forest Management Unit (FMU) of 50 Kota district is one of the Forest Management Units in Indonesia, whose appointment is through the Minister of Forestry Decree No.44 / Menhut-II / 2012 on 2 February, 2012, with $\pm 117,552$ Ha. In Jorong Landai with the total area of $1383 \mathrm{Ha}$, part of area has been claimed by government as protected forest of 880,33 Ha. Tha claims area In Jorong Landai, make overlapping areas between local communities (ulayat land) and government (protected forest).

The history of land in Jorong Landai between ulayat land and protected forest make a shift in land use and land positions in Jorong Landai. The land claim change transition that occurred in Jorong Landai at this time in Figure 3 below:

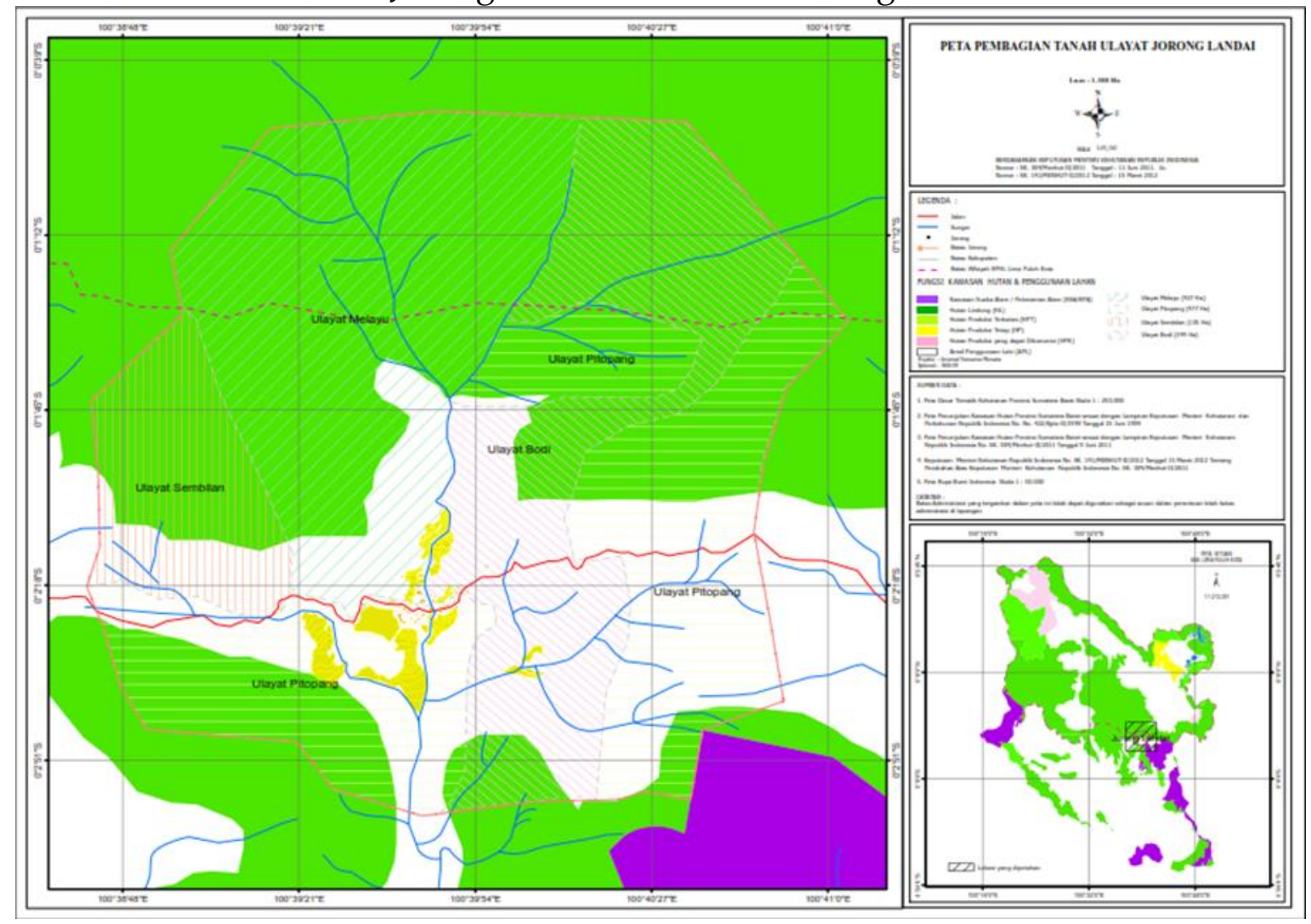

Figure 1. Claim of Land in The Jorong Landai Source: Forest Management Unit 50 Kota District 
From Figure above, The area in Jorong Landai of 1383 Ha and have the transition claims of land use. The borders established by the government in Minister of Forestry Decree No.44 / Menhut-II / 2012 on 2 February. The rule cause overlapping claims use of land area between them (local community and government). Before 2012, governmentdesignated protection forest is only at the edge of the Jorong Landai, but after the establishment of new protected forest areas by the government, under the supervision of the FMU of 50 Kota District, the boundaries of the former protection forests have changed considerably. The new boundaries by the government, based on watershed and boundary district, its make changes the boundaries before.

All land in Indonesia, can be categorized legally according to its use. Land use, the existence of rights and permission to manage a land are determined through the classification of land use in an area in Indonesia, which is classified as a forest area or non-forest area (Other Use Areas / APL). for forest areas, divided according to their functions, namely protected forests that function as areas that cannot be cut down by trees, can only utilize forest products (honey, herbal medicines, etc.), then conservation forests, which are the most guarded and production forests, which can be used for enjoyed the forest (can be used wood that is ready to harvest) (World Resource Institute, 2013).

The attachment between the person and the land they possess, becomes very complex with various dimensions, so the process of taking the land without the "willingness" of the right holder will cause many problems. The issue of land acquisition, the revocation of rights or the disposal of rights or any of its names always involves two dimensions, which must be fair between the interests of the government and the interests of the people. Two parties involved are "rulers" and "the people" must both observe and comply with the applicable provisions on the matter. If it is ignored will arise problems that can trigger a dispute (Amahorseya, 2008). The claim land use between local communities (ulayat land) with the government (protected forest) makes a dispute between them.

\section{Land Use}

The land has different uses and can change with the times. The community can determine the land use they want. Land can be divided according to its uses like (FAO/UNEP 1999 complemented): many raw materials and minerals exist in the soil and can be used by humans; place of production, where land can be used in industrial or agricultural matters which will produce various human needs such as food, needs in fuel, yarn for clothing, etc.; Shelter or human settlement, can be used as infrastructure in a variety of interests (tourism, environmental improvement, and other facilities); In improving the environment, soils can also be used as land in pollution filters such as chemical waste, gas products from greenhouses and also used as an environmental buffer.; Provide groundwater and surface water; A place or habitat for living things (an- 
imals, plants, and micro-organisms); Is the main thing insecurity, can be in the form of shelter and for a living Is a social identity, because it is a place of homeland for the community/tribe/family; Is a place of ancestors that has meaning, both in terms of religious or spiritual; Can be used as evidence or storage of evidence from pre-history / history in the form of archeological remains, the past, fossils, etc.); A symbol or used as a sign of someone's freedom.; Object in speculation and investment; Used as an object that can / will be taxed; Is a basis for dependency and strength. Land that has different uses can also experience overlapping when viewed from land use. however, there are lands that can eliminate a benefit/function while others can require the function of that land. such as the benefits of the land are eliminated if used to extract raw materials or minerals and its functions will be needed if used for agricultural land, road infrastructure, or for industry, etc. (BMZ, 2011)

Land that is used can affect a variety of things, such as human well-being, as a goal to achieve the desired environmental sustainability, social inclusion, and economic growth. in planning spatial or land use or environmental regulations and regulations in development requires public policy to influence land use. the above can reduce or limit how the land can be used, but it will not be able to shake the community/individual in managing their land. they will need time to make the desired changes. in addition, no less important, land use is very important because humans have a close relationship with the land. probe the city, whether the city is considered or how. very interesting if you see the use of land that can be utilized. land makes the relationship between ownership and land used also closely related to various aspects such as cultural aspects in society. the many benefits and uses of the land, it is not surprising if there are often debates or conflicts in land use policies (OECD, 2017).

Urban and regional planning for centuries cannot be separated from changes in land use which is an important aspect. most of the research conducted uses the independent variable with the highest correlation on changes that occur. Verburg et al.; Saputra and Lee, 2019 lays out in measuring confusion requiring a new technique of multiscale characteristics of land use systems e_ects. Furthermore, Verburg et al.; Saputra and Lee, 2019 in addition, it is also related to temporal dynamics and achieving a high level of integration among models that study changes in rural and urban land use and between disciplinary approaches. (Saputra \& Lee, 2019). changes in land use have an impact on the physical nature of the land, especially if the conservation of tropical forests is changing the function of land use into agricultural land or grasslands. changes in penetration resistance, near-surface hydraulic conductivity, bulk density, and infiltrability are described as risks that will occur from changes in land use. (Dionizio and Costa, 2019). 


\section{Land Use by Local Communities in the Jorong Landai}

In the Jorong Landai with the total area of 1388 Ha with has ulayat land as follows table 4 below:

Table 2. The Ulayat Land in Jorong Landai

\begin{tabular}{ccc}
\hline No & Name of Clan & Amount \\
\hline 1 & Ulayat Pitopang & $477 \mathrm{Ha}$ \\
2 & Ulayat Melayu & $427 \mathrm{Ha}$ \\
3 & Ulayat Bodi & $344 \mathrm{Ha}$ \\
4 & Ulayat Sambilan & $135 \mathrm{Ha}$ \\
\hline \multicolumn{2}{c}{ Amount of Ulayat Land in Jorong Landai } & $1383 \mathrm{Ha}$ \\
\hline
\end{tabular}

The ulayat Pitopang $477 \mathrm{Ha}$, ulayat Bodi $344 \mathrm{Ha}$, ulayat Melayu $427 \mathrm{Ha}$ and ulayat Sambilan $135 \mathrm{Ha}$. According to the head of Jorong Landai. Ulayat land is used by the community as a place of building settlements, to plant gambir and to rice fields.

\section{Land Use in Jorong Landai by FMU of 50 Kota District}

In the era of decentralization, in carrying out management missions, the central government launched a range of policies that are expected to promote the establishment of conservation and prosperity of forest communities, while accommodating the demands and interests of local governments. One of the policies developed is what is stated in Regulation No. 6/2007 Forest Management Unit (FMU). Ministry of Forestry Planning Agency (2006) stated that the establishment of FMU aims to carry out forest management activities in a sustainable and efficient manner by providing a platform. At first glance, this concept appears to be a promising realization of more accountable and sustainable forest management in the future (Ngakan, et al., 2008).

The Ministry of Forestry realized many of the weaknesses in forest management over the years. Learning the past prove that the grant management rights to private parties large investors did not improve the condition of forests in Indonesia. Forest Management Unit (FMU) are expected to improve forest governance in Indonesia. At the global level actually occurred three phases of evolution of forest governance ranging from: 1) Phase I: Phase Sustainable Forest Management, with formulation of indicator and criterias for sustainable forest management, which is led by the International Tropical Timber Organization (ITTO), 2) phase II: phase legality of timber through certification to tackling illegal logging, which was initiated by the Forest Law Enforcement and Governance (FLEG) and the Forest Law Enforcement and Governance and Trade (FLEGT), 3) phase III: phase carbon through the program Reducing Emissions from Deforestation and Degradation (REDD +), championed by the World Bank's Forest Carbon Partnership Facility (FCPF) and Forest Investment Programme (FIP) (McDermot, 2014). The third phase has been and is being applied in forest management in Indonesia. The 
Indonesian Government (cq Ministry of Forestry) and then formulate its own concept of forest governance in the form of FMU development (Ekawati, 2014).

The FMU of 50 Kota district through the Minister of Forestry Decree No. 44/Menhut-II/2012 dated February 2, on Determination of Forest Management Unit (FMU) of 50 Kota district (unit II) located in West Sumatera Province covering \pm 117,552 Ha. FMU area of 50 Kota district has a strategic position which is in the province area West Sumatera and directly adjacent to Riau Province. The management of this area is at the Regional Technical Implementation Unit (UPTD) of the Forest Protection Unit of 50 Kota district under the Department of Forestry and Mining of 50 Kota district Regency established through the Regent Regulation of 50 Kota district No: 122 of 2011. (KPH 50 Kota, 2013).

In Jorong Landai, have the area of protected forest of 880,33 Ha. The FMU of 50 Kota district expects that the protected forest can be felt by the local communities and also for others because have the fundamental advantages as buffering and protecting living systems to maintain land subsidence, prevent or avoid flooding, support intrusion of sea water to keep it well, control against erosion and regulate existing water.

The FMU of 50 Kota district in Jorong Landai, has the several programs that are planned in there is the establishment of PLMTH and PDAM, because in the Jorong Landai there is a water source, known as Malanca waterfall. The water source Malancah, used by local communities as clean water, irrigation fields and for daily activities. The Malanca waterfalls will also planned as ecotourism by FMU of 50 Kota district. The good atmosphere and nice scenery make the waterfall Malanca potential as an ecotourist in Jorong Landai.

According to the plan FMU of 50 Kota district for development ecotourism in Jorong Landai (at RHPJP KPHL Kabupaten 50 Kota), this is should have started since 2014, but until now, the Malanca waterfall is still in transition stage, introduction of ecotourism and cooperation process between FMU of 50 Kota district with local communities. Access and promotion of Malanca waterfalls has begun to be disseminated, including to road improvements and also the establishment of a plank of ecotourism area of Malanca waterfall before entering into Jorong Landai.

The FMU of 50 Kota district is managed by 67 people, are have a job as implementers, secretariat, forest planning and protection, counseling and rehabilitation of protection forest (RHL) and Forest Police (Polhut). Administratively the government of FMU of 50 Kota district is located in 5 sub-districts, are Bukit Barisan Sub-district, Kapur IX Sub-district, Mungka Sub-district, Harau District and Pangkalan Koto Baru Subdistrict, consisting of 21 Nagari with the Resort Management of Forest (RPH) of $6 \mathrm{RPH}$, that established in accordance with the landscape and the proximity of the management site. 


\section{CONCLUSION}

The local communities, claim the land with their ulayat land and each clan has the area: ulayat Bodi: $344 \mathrm{Ha}$, ulayat Pitopang $477 \mathrm{Ha}$, ulayat Sambilan of $135 \mathrm{Ha}$ and ulayat Melayu $427 \mathrm{Ha}$. Besides that, the government claims part of the area in Jorong Landai as the protected forest of 880,33 Ha and the other area of use (Area Penggunaan Lain) is an area of 507,67 Ha. The map gives us drawing about the area of ulayat land that has a whole overlaps claim with protected forests. Protected forest and ulayat land have two different use of land but have the same vision are, to the welfare of the community. The sustainable forest will produce the good thing and communities can get benefit from that, such as timber forest products and nontimber forest products. Protected forest areas in Jorong Landai under FMU of 50 Kota District were agreed by the government in 2012, using the ministerial decree with the determination of boundaries of district and river basin. Regarding the boundaries of protected forest areas, FMU of 50 Kota district and forestry services 50 Kota has provided counseling and communication to the community in the 50 Kota district, including in Jorong Landai.

Protection forests are forest areas that have been established by a certain government or community groups to be protected so that their ecological functionsparticularly with regard to soil water and soil fertility-can still be run and enjoyed by the surrounding communities. The function of the protected forest is to the protection of life system supporters to regulate guard against erosion, maintain soil fertility, avoid flooding and is a water system. Other areas use (APL) are areas that the Ministry of Forestry is allocating for community management, through regent permits, and are likely to be used for oil palm or mining plantations.

\section{REFERENCES}

1. Amahorseya, R. (2008). Penyelesaian Sengketa Tanah Hak Ulayat di Kabupaten Nabire Provinsi Papua (Studi Kasus Sengketa Tanah Bandar Udara Nabire) (Doctoral Dissertation, PROGRAM PASCA SARJANA UNIVERSITAS DIPONEGORO).

2. Astuti, N. B. (2009). Transformasi Dari Desa Kembali Ke Nagari (Studi Kasus Di Kenagarian IV Koto Palembayan, Sumatera Barat). (Thesis Program Pascasarjana Institut Pertanian Bogor).

3. GIZ, D. (2012). Land use planning: Concept, tools and applications. Eschborn, Germany: Federal Ministry for Economic Cooperation and Development (BMZ).

4. Dionizio, E. A., \& Costa, M. H. (2019). Influence of land use and land cover on hydraulic and physical soil properties at the cerrado agricultural frontier. Agriculture, 9(1), 24.

5. Ekawati, S. (2014). Apakah yang dimaksud dengan kesatuan pengelolaan hutan (KPH). Operasionalisasi Kesatuan Pengelolaan Hutan (KPH): Langkah Awal Menuju Kemandirian. Penerbit PT Kanisius, 1-20. 
6. Food and Agriculture Organization (FAO). (2010). Land and Property Rights, Junior Farmer Field and Life School-Facilitator's Guide. Rome: Viale delle Terme di Caracalla.

7. Heryani, E., \& C. Grant, C. (2004). Land Administration in Indonesia. Jakarta, October 3-7 2004. FIG Regional Conference. pp 1-14.

8. Kesatuan Pengelolaan Hutan (KPH 50 Kota). (2013). Rencana Pengelolaan Hutan Jangka Panjang KPHL Model 50 Kota Kabupaten 50 Kota Propinsi Sumatera Barat Tahun 2013-2022.

9. Medaline, O. (2018). The Development of "Waqf" on the "Ulayat" Lands in West Sumatera, Indonesia. Macrothink Institute, 5(1), 108-114.

10. Ngakan, P.O., Komarudin, H., Moeliono, M. 2008. Menerawang kesatuan pengelolaan hutan di era otonomi daerah. CIFOR Governance Brief No.38. Bogor, Indonesia, Center for International Forestry Research (CIFOR). 12p. ISSN: 1907-4212.

11. Organization for Economic Cooperation and Development (OECD). (2017). The Governance of Land Use Policy Hughlights. OECD.

12. Rights and Resources Initiative (RRI). (2015). Who Owns the World's Land? A Global Baseline of Formally Recognized Indigenous \& Community Land Rights. Washington.

13. Saputra, M. H., \& Lee, H. S. (2019). Prediction of Land Use and Land Cover Changes for North Sumatra, Indonesia, Using an Artificial-Neural-Network-Based Cellular Automaton. Sustainability, 11(11), 3024.

14. Waiganjo, C., \& Ngugi, P. E. (2001). The effects of existing land tenure systems on land use in Kenya today. In Proceedings International Conference on Spatial Information for Sustainable Development paper number TS6. 2, ISK/FIG/UN Nairobi Kenya Williamson IP, 2000, Best Practices for Land Administration Systems in Developing Countries, Proceedings International $C$.

15. Rosenbarger, A., Gingold, B., Prasodjo, R., Alisjahbana, A., Putraditama, A., \& Tresya, D. (2013). How to Change Legal Land Use Classifications to Support More Sustainable Palm Oil Production in Indonesia. World Resources Institute, Washington, DC, USA. 